\title{
Interpersonal Relationships on and outside of the Job and Satisfaction with Working Conditions in Europe
}

\author{
Nunzia Nappo \\ Assistant Professor of Economics \\ Department of Political Science \\ University of Napoli "Federico II" \\ Via Rodinò 22 - 80134 Napoli - Italy
}

\begin{abstract}
The aim of this paper is to analyse, using a standard probit model, the correlates of satisfaction with working conditions in Europe. The main assumption of the paper is that employees' satisfaction with working conditions depends not only on standard variables that explain satisfaction but also on employees' interpersonal relationships on and outside of the job. The econometric analysis employs data from the Sixth European Working Conditions Survey carried on in 2015 and released in 2017. Findings show that interpersonal relations count at various level for satisfaction with a positive association between relationships on and outside of the job and satisfaction with working conditions.
\end{abstract}

Keywords: working conditions satisfaction; interpersonal relationships; Europe; probit model.

\section{Introduction}

The link between working conditions and job performance is well established in literature (Naharuddin and Sadegi 2013; Chandrasekarr 2011): it seems that working conditions could be considered as key factors affecting performance of employees. Since firms aim at improving job performance in order to maximize their profit (Bevan 2012), they should pay great attention at working conditions and at employees working conditions satisfaction: when employees have negative perception of their work environment, and are not satisfied with working conditions, they tend to suffer from chronic stress, absenteeism, and their productivity and commitment are likely low. On the contrary, when employees are satisfied they tend to enhance their productivity: this is likely to happen within a work environment characterized by "favourable" working conditions.

The concept of working conditions is a very broad one and it has been evolving over time. For the International Labour Organization (2016) working conditions cover a "broad range of topics and issues, from working time (hours of work, rest periods, and work schedules) to remuneration, as well as the physical conditions and mental demands that exist in the workplace". The European Union (2019) definition of working conditions is even more extensive and it" refers to the working environment and aspects of an employee's terms and conditions of employment. This covers such matters as the organisation of work and work activities; training, skills and employability; health, safety and well-being; working time and work-life balance". The above definition provides a very broad concept of working conditions, therefore satisfaction with working conditions is likely to be influenced not only by standard working related variables but also by variables generally not addressed such as interpersonal interactions which are important for individual wellbeing: workers are social beings, and as such, they commonly value social interactions.

The main aim of this paper is studying the link between interpersonal relationships on and outside of the job and satisfaction with working conditions in Europe, moving from the idea that social interactions are important for individual well-being(see Becchetti et al., 2008, 2011; Bruni and Stanca, 2008)and therefore, they could influence satisfaction with working conditions. More precisely, good relationships on the job, with colleagues and with superiors, reducing (buffer) stressful situations (Baum 1999; McKenzie et al. 2002), are likely to increase satisfaction with working conditions, since they could counteract potential negative effects of less favourable working conditions. As regards interactions outside of the job, being satisfaction with working conditions a "multifaceted feeling", other aspects of the individuals' relational sphere could influence it as well: these aspects could include volunteering and participation in sport and recreational activities. Interpersonal relationships, which arise from these activities, may influence satisfaction with working conditions because they could be useful to earn higher salaries and to improve workers' career prospects. The empirical analysis employs data from the Sixth European Working Conditions Survey (EWCS) released in 2017. The Survey presents the varied picture of Europe at work over time and across countries, occupations, gender and age groups. 
The paper focuses on the EU28.The dependent variable is "satisfaction with working conditions" (Q88 in the Questionnaire) - a subjective measure of satisfaction - collected through individual interviews. As regards independent variables, controlling for several standard demographics variables, the selection of proper explanatory variables moves from the idea that interpersonal relationships are important for satisfaction with working conditions. The theoretical hypothesis concerning the association between interpersonal relationships and satisfaction with working conditions is tested using a standard probit model; however, outcomes of the econometric analysis describe a correlation rather than a cause-and-effect relation between interpersonal relationships and satisfaction with working conditions. The original contribution of the paper to the literature is threefold. First, the study uses EWCS (2017) data to analyse the association between satisfaction with working conditions and interpersonal relationships. It is the first time that this release of the data has been employed for this kind of investigation. Second, to the best of our knowledge, there are no papers, which have as dependent variable satisfaction with working conditions and study its association with interpersonal relationships on and outside of the job. Third, the paper considers a large group of countries (EU28), and therefore provides a broad picture of the importance of social relations in terms of satisfaction with working conditions across Europe at work.

The paper is organized as follows. Section 2 reviews the literature on the importance of interpersonal relationships for workers and proposes potential channels through which social interactions could influence satisfaction with working conditions. Section 3 describes the data and the methodology. Section 4 illustrates and discusses the results from the econometric analysis. The last section concludes and provides some policy suggestions.

\section{Interpersonal relationships on the job and outside the job}

Workers are social beings, for this reason they appreciate social interactions in general, and in particular, positive relationships on the job given that they spend many hours working and work plays a central role in their lives. According to Katzell and Thompson (1990), social-interpersonal relationships among workers and their qualityare important for creating more motivating work environments. Employees may derive from on-the-job relationships benefits that meet their needs. On the contrary, poor quality relationships with co-workers may create an unpleasant work environment. In work situations and within the organization interpersonal relationships can become a motivation to cooperate productively (Robbins and Judge 2013);hence, employees improve their levels of satisfaction. Morrison (2004) focuses on the beneficial outcomes of relationships on the job for workers, in terms of trust, cooperation, esteem and behaviour. According to Morrison (2004), on-the job relationships can influence employees performance, and their productivity, and in turn, organizations indirectly benefit from these relationships.

Several research (see among others De Neve, Krekel, Ward 2018; Carder 2019) show that social relationships on the job are, in order of importance, the first drivers of workers satisfaction. According to Chandrasekar (2011), it seems that "human to human interactions" and relations play a very central role in the overall job satisfaction more than money. Indeed, one of the main "lesson" that comes from the Global Happiness and Wellbeing Policy Report (2019) is that firms should invest much more in employees' well-being by targeting social relationships on the job.

As regards interpersonal relationships outside of the work environment, we suppose that social interactions outside of the job could enhance satisfaction with working conditions as well; however, the link between satisfaction with working conditions and social contacts has been scarcely studied(see Fiorillo and Nappo 2014).Social interactions outside of the job are likely to influence satisfaction with working conditions since relational contacts may have a significant part in job searches: very often contacts provide information and help to find a job (Ponzo and Scoppa 2010).Facets of the private relational sphere of individuals that could influence satisfaction with working conditions could be those activities that imply multiple interpersonal interactions such as volunteering and sporting, cultural and leisure activities, which involve contacts with others. As known, volunteering, which implies production and consumption of relational goods (see among others Nappo and Verde 2010), is likely to enable people to reach better positions on the job market since volunteers gain work experience and earning power. Therefore, it could be hypothesised that volunteering increases satisfaction with working conditions because of the wage premium, which it implies, and because it improves workers' career prospects (Wilson 2000).

As concerns sporting, cultural and leisure activities, they are supposed to facilitate the transmission of information on vacancies. Those activities easily become ideal places where people discuss work related issues and share their work experiences. Such confidential networks of information boost employees to assume proper behaviours, which, in turn, are likely to improve facets of satisfaction with working conditions.

In addition, both volunteering and sporting, cultural and leisure activities offer emotional support, which, in turn, could lessen work related stress, increasing satisfaction. 
Furthermore, all those activities and good relations on the job as well are likely to make workers feeling part of a group. Following Maslow (1954), the need to belong is a major source of human motivation, feeling accepted as a member of a group, and of a work group, within which there are good relationships, motivates people to perform their job with more satisfaction.

\section{Sample description}

The econometric analysis employs individual data provided by the Sixth European Working Conditions Survey (EWCS 2017) carried on in 2015 and released in 2017. Data were accessed and downloaded via the UK Data Service. The Survey presents the varied picture of Europe at work over time across countries, occupations, gender and age groups. Since its launch in 1990, the European Working Conditions Survey has provided an overview of working conditions in Europe. A random sample of workers is interviewed face to face. Overall approximately 43.000 workers aged 15 and over, have been interviewed. The questionnaire includes topics related to employment status, working time duration and organisation, work organisation, learning and training, physical and psychosocial risk factors, health and safety, work-life balance, workers participation, earnings and financial security, as well as work and health. The total number of countries in the sample is 35, including the EU28, Norway, Switzerland, Albania, the Former Yugoslav Republic of Macedonia, Montenegro, Serbia and Turkey. No panel dimension is available.

The econometric analysis focuses on EU28 countries and it includes the following countries: Austria, Belgium, Bulgaria, Czech Republic, Denmark, Germany, Estonia, Ireland, Greece, Spain, France, Croatia, Italy, Cyprus, Latvia, Lithuania, Luxembourg, Hungary, Malta, the Netherlands, Poland, Portugal, Romania, Slovenia, Slovakia, Finland, Sweden, and the United Kingdom.

The Survey contains information on both employed and self-employed workers; however, the econometric analysis focuses on employed workers.

After removing unselected respondents and missing variables on dependent and independent variables, the final data set is a cross-section sample of 18.616 observations.

\subsection{Dependent variable}

Our dependent variable is Satisfaction with working conditions (Question n. 88 in the EWCS6Questionnaire). Satisfaction with working conditions is going to be considered as a subjective indicator of satisfaction: it could be considered not just a "facet", but a proxy of job satisfaction. This is possible considering the open concepts of working conditions provided in section 1: variables that influence satisfaction with working conditions are very numerous and, for this reason, in some ways, satisfaction with working conditions could be assimilated with job satisfaction, having both similar determinants(Pires 2018).Moving from these considerations, we are going to refer to satisfaction with working conditions and to job satisfaction indifferently.

Satisfaction with working conditions has been collected through individual interviews. Interviewed responded to the question: "On the whole, are you very satisfied, satisfied, not very satisfied or not at all satisfied with working conditions in your main paid job?"

The $23.31 \%$ (54.37\% females) of the sample (18,616observations) reported of being very satisfied; the $61.32 \%(51.45 \%$ females) were satisfied; the $12.66 \%$ (51.70\% females)not very satisfied; the $2.71 \%(49.77 \%$ females $)$ not at all satisfied.

For reasons of convenience, we aggregate positive responses (very satisfied and satisfied) and negative responses (not very satisfied and not at all satisfied)so that we consider satisfaction with working conditions as a binary variable.

\subsection{Independent variables}

The choice of appropriate explanatory variables is driven by theory (however, as said in section 1 there are very few studies that focus on the association between satisfaction with working conditions and on and outside of the job relationships) and specially by the aim of the paper. In addition to relational variables, a number of standard socioeconomic control variables are included in the econometric analysis. Table 1 and Table laprovide respectively a description of the independent variables used in the empirical model and the descriptive statistics for the sample(for brevity, both tables do not contain the 28 country dummies). 
Table 1. Definition of the Independent Variables.

\begin{tabular}{|c|c|}
\hline Variable & Description \\
\hline \multicolumn{2}{|l|}{ Demographic } \\
\hline Male & 1 if male; 0 otherwise \\
\hline Age1 & Age in years at the time of the survey interview - $15 / 34$ years, 0 otherwise \\
\hline Age2 & Age in years at the time of the survey interview $-35 / 54$ years, 0 otherwise \\
\hline Age3 & Age in years at the time of the survey interview $-55 / 74$ years, 0 otherwise \\
\hline Age4 & $\begin{array}{l}\text { Age in years at the time of the survey interview - } 75 / 89 \text { years, } 0 \text { otherwise } \\
\text { (reference group) }\end{array}$ \\
\hline Has a spouse or a partner & 1 if she/he has a spouse or a partner, 0 otherwise \\
\hline Has a child & 1 if she/he has at least one child and 0 otherwise \\
\hline Low level of education & $\begin{array}{l}1 \text { if highest level of education is primary education, } 0 \text { otherwise } \\
\text { (reference group) }\end{array}$ \\
\hline Middle level of education & 1 if highest level of education is secondary education, 0 otherwise \\
\hline High level of education & 1 if highest level of education is tertiary education, 0 otherwise \\
\hline Ends meet & $\begin{array}{l}\text { How the interviewee household total monthly income is able to make ends meet (from } 1 \text { very easily } \\
\text { to } 6 \text { with great difficulty) }\end{array}$ \\
\hline \multicolumn{2}{|l|}{ Job characteristics } \\
\hline Permanent job & 1 if the employment contract has an unlimited duration, 0 otherwise \\
\hline Part time job & 1 if she/he works part time, 0 otherwise \\
\hline How many hours1 & $\begin{array}{l}\text { N. of hours the interviewee usually works per week }-1 / 20 \text { hours, } 0 \text { otherwise } \\
\text { (reference group) }\end{array}$ \\
\hline How many hours2 & N. of hours the interviewee usually works per week- 21/40hours, 0 otherwise \\
\hline How many hours 3 & N. of hours the interviewee usually works per week $-41 / 50$ hours, 0 otherwise \\
\hline How many hours4 & N. of hours the interviewee usually works per week- $51 / 105$ hours, 0 otherwise \\
\hline Health risk & 1 if the worker thinks that her/his health or safety is at risk because of her/his work, 0 otherwise \\
\hline Stress1 & 1 if she/he experiences stress in her/his work (always, most of the time), 0 otherwise \\
\hline Stress2 & 1 if she/he experiences stress in her/his work (sometimes), 0 otherwise \\
\hline Stress 3 & $\begin{array}{l}1 \text { if she/he experiences stress in her/his work (rarely, never), } 0 \text { otherwise } \\
\text { (reference group) }\end{array}$ \\
\hline Work affects health1 & 1 if her/his work affects healthmainly positively, 0 otherwise \\
\hline Work affects health2 & 1 if her/his work affects health mainly negatively, 0 otherwise \\
\hline Work affects health 3 & 1 if her/his work does not affect health, 0 otherwise (reference group) \\
\hline External Contacts & $\begin{array}{l}1 \text { if her/his work involves visiting customers, patients, clients or working at their premises or in their } \\
\text { home, } 0 \text { otherwise }\end{array}$ \\
\hline Work and Family & $\begin{array}{l}1 \text { if her/his working hours fits in with her/his family or social commitments outside work, } 0 \\
\text { otherwise }\end{array}$ \\
\hline Trade Union & 1 if within her/his company or organisation there is trade union, 0 otherwise \\
\hline \multicolumn{2}{|l|}{ Relationships on the job } \\
\hline Colleagues Support1 & 1 if her/his colleagues help and support her/him (always, most of the time), 0 otherwise \\
\hline Colleagues Support2 & 1 if her/his colleagues help and support her/him (sometimes), 0 otherwise \\
\hline Colleagues Support3 & $\begin{array}{l}1 \text { if her/his colleagues help and support her/him (rarely, never), } 0 \text { otherwise } \\
\text { (reference group) }\end{array}$ \\
\hline Manager Support1 & 1 if her/his manager helps and supports her/him (always, most of the time), 0 otherwise \\
\hline Manager Support2 & 1 if her/his manager helps and supports her/him (sometimes), 0 otherwise \\
\hline Manager Support3 & $\begin{array}{l}1 \text { if her/his manager helps and supports her/him (rarely, never), } 0 \text { otherwise } \\
\text { (reference group) }\end{array}$ \\
\hline Colleagues Cooperation & $\begin{array}{l}\text { If there is good cooperation between she/he and her/his colleagues(from } 1 \text { strongly agree to } 6 \\
\text { strongly disagree) }\end{array}$ \\
\hline Get on well Colleagues & $\begin{array}{l}\text { If generally she/he gets on well with her/his work colleagues(from } 1 \text { strongly agree to } 6 \text { strongly } \\
\text { disagree) }\end{array}$ \\
\hline \multicolumn{2}{|l|}{ Relationships outside the job } \\
\hline Volunteering & 1 if she/he performs volunteer activities, 0 otherwise \\
\hline $\begin{array}{l}\text { Recreational activities } \\
\text { Job sector }\end{array}$ & 1 if she/he performs sporting, cultural or leisure activity outside her/his home, 0 otherwise \\
\hline Private & 1 if the interviewee works in the private sector, 0 otherwise \\
\hline Public & 1 if the interviewee works in the public sector, 0 otherwise \\
\hline Other & $\begin{array}{l}1 \text { if the interviewee works in a joint private-public organisation or company or the not-for-profit } \\
\text { sector or an NGO or other, } 0 \text { otherwise(reference group) }\end{array}$ \\
\hline \multicolumn{2}{|l|}{ Kind of occupation } \\
\hline Armed forces & 1 if the worker perform an armed forces occupation, 0 otherwise \\
\hline Managers & 1 if the worker is a manager, 0 otherwise \\
\hline Professionals & 1 if the worker is a professional, 0 otherwise \\
\hline Technicians & 1 if the worker is a technician, 0 otherwise \\
\hline Clerical & 1 if the worker is a clerical support worker, 0 otherwise \\
\hline Service sales & 1 if the worker is a service and sales worker, 0 otherwise \\
\hline Skilled agricultural forestry fish & 1 if the worker is a skilled agricultural, forestry and fish worker, 0 otherwise \\
\hline Craft trades & 1 if the worker is craft and related trades worker, 0 otherwise \\
\hline Plant machine & 1 if the worker is a plant and machine operators, and assemblers, 0 otherwise \\
\hline Elementary occupation & $\begin{array}{l}1 \text { if the worker perform an elementary occupation, } 0 \text { otherwise } \\
\text { (reference group) }\end{array}$ \\
\hline
\end{tabular}


Table 1a.Descriptive Statistics of the Independent Variables.

\begin{tabular}{|c|c|c|c|c|}
\hline Variable & Mean & Std. Dev. & Min & $\operatorname{Max}$ \\
\hline \multicolumn{5}{|l|}{ Demographic } \\
\hline Male & .4784071 & .4995439 & 0 & 1 \\
\hline Age1 & .2751678 & .4466081 & 0 & 1 \\
\hline Age2 & .5275335 & .4992517 & 0 & 1 \\
\hline Age3 & .1947142 & .3959888 & 0 & 1 \\
\hline Age4 & .0025845 & .0507735 & 0 & 1 \\
\hline Has a spouse or a partner & .6060858 & .4886264 & 0 & 1 \\
\hline Has a child & .3896384 & .4876784 & 0 & 1 \\
\hline Low level of education & .1956358 & .3966977 & 0 & 1 \\
\hline Middle level of education & 689753 & .4626043 & 0 & 1 \\
\hline High level of education & .1146111 & .3185587 & 0 & 1 \\
\hline End meet & 3.289682 & 1.226742 & 1 & 6 \\
\hline \multicolumn{5}{|l|}{ Job characteristics } \\
\hline Permanent job & .7733405 & .4186792 & 0 & 1 \\
\hline Part time job & .2021987 & .4016484 & 0 & 1 \\
\hline How many hours 1 & .1292278 & .335459 & 0 & 1 \\
\hline How many hours 2 & .6782657 & .4671516 & 0 & 1 \\
\hline How many hours3 & .1530898 & .3600816 & 0 & 1 \\
\hline How many hours 4 & .0394168 & .1945886 & 0 & 1 \\
\hline Health risk & .2632246 & .4403926 & 0 & 1 \\
\hline Stress 1 & .2561103 & .4364926 & 0 & 1 \\
\hline Stress2 & .3805724 & .4855377 & 0 & 1 \\
\hline Stress3 & .3633173 & .4809652 & 0 & 1 \\
\hline Work affects health1 & .1071383 & .3092956 & 0 & 1 \\
\hline Work affects health2 & .2878003 & .4527472 & 0 & 1 \\
\hline Work affects health3 & .6050614 & .488848 & 0 & 1 \\
\hline External Contacts & .2264559 & .4185462 & 0 & 1 \\
\hline Work and Family & .8280879 & .3773119 & 0 & 1 \\
\hline Trade Union & .4649031 & .4987776 & 0 & 1 \\
\hline \multicolumn{5}{|l|}{ Relationships on the job } \\
\hline Colleagues Support1 & .7552444 & .4299517 & 0 & 1 \\
\hline Colleagues Support2 & .157488 & .3642683 & 0 & 1 \\
\hline Colleagues Support3 & .0872676 & .282233 & 0 & 1 \\
\hline Manager Support1 & .633146 & .4819565 & 0 & 1 \\
\hline Manager Support2 & .2045991 & .403417 & 0 & 1 \\
\hline Manager Support3 & .1622549 & .3686924 & 0 & 1 \\
\hline Colleagues Cooperation & 1.649882 & .7815728 & 1 & 5 \\
\hline Get on well Colleagues & 1.577518 & .7487219 & 1 & 5 \\
\hline \multicolumn{5}{|l|}{ Relationships outside the job } \\
\hline Volunteering & .2998002 & .4581799 & 0 & 1 \\
\hline Recreational activities & .7208403 & .4485955 & 0 & 1 \\
\hline \multicolumn{5}{|l|}{ Job sector } \\
\hline Private & .6936534 & .460985 & 0 & 1 \\
\hline Public & .2470146 & .4312843 & 0 & 1 \\
\hline Other & .0593319 & .2362499 & 0 & 1 \\
\hline \multicolumn{5}{|l|}{ Kind of occupation } \\
\hline Armed forces & .0047445 & .0687179 & 0 & 1 \\
\hline Managers & .0376228 & .1902861 & 0 & 1 \\
\hline Professionals & .1298069 & .3360978 & 0 & 1 \\
\hline Technicians & .1158232 & .3200195 & 0 & 1 \\
\hline Clerical & .1060846 & .3079522 & 0 & 1 \\
\hline Service sales & .2437989 & .4293817 & 0 & 1 \\
\hline Skilled agricultural forestry fish & .0118195 & .1080756 & 0 & 1 \\
\hline Craft trades & .1311387 & .337559 & 0 & 1 \\
\hline Plant machine & .0889795 & .2847201 & 0 & 1 \\
\hline Elementary occupation & .1301815 & .33651 & 0 & 1 \\
\hline
\end{tabular}

\subsection{The econometric model}

The theoretical hypothesis concerning the association between relationships on and outside the job and satisfaction with working conditions is tested using a standard probit model that is generally used to analyse discrete data of this type. The model takes the following form: 
$P_{r}\left(Y_{i}=1\right)=\phi\left(x_{i} \beta\right)(1)$

where $\phi$ represents the cumulative normal distribution function, $x$ is a vector of explanatory variables, $\beta$ is a vector of parameter estimates, subscript $i$ denotes an individual observation.

\section{Results}

It seems appropriate to underline that outcomes of the econometric analyses, a cross-sectional study (no panel dimension is available) describe a correlation rather than a cause-and-effect relation between on and outside the job relationships and satisfaction with working conditions: association does not imply causation. Our estimates do not find a clear causal relationship in one direction or in the other: it is rational to suppose that causation could go in both directions, with the workers who are satisfied with working conditions entertaining more on and outside of the job relationships, and with on and outside of the job relationships making workers satisfied with working conditions. However, estimation of the marginal effects allows for interpreting the effect of the regressors on the dependent variable. Table 2 reports the probit estimates for satisfaction with working conditions keeping in mind that in standard probit models, it is possible to interpret just the sign of the coefficient but not the magnitude. A test for correct model specification was run. Table 3 reports the results.

Table 2. Correlates of satisfaction with working conditions.

\begin{tabular}{|c|c|c|c|}
\hline \multirow{2}{*}{\multicolumn{4}{|c|}{$\begin{array}{l}\text { Regressors } \\
\text { Variable }\end{array}$}} \\
\hline & & & \\
\hline \multicolumn{4}{|l|}{ Demographic } \\
\hline Male & .0001937 & .0306831 & 0.995 \\
\hline Agel & $-5.092567 * * *$ & .2079508 & 0.000 \\
\hline $\mathrm{Age} 2$ & $-5.086468^{* * * *}$ & .2117357 & 0.000 \\
\hline Age3 & $-5.111539^{* * *}$ & .2088779 & 0.000 \\
\hline Has a spouse or a partner & -.0198713 & .0317056 & 0.531 \\
\hline Has a child & $.1112336^{* * *}$ & .0329086 & 0.001 \\
\hline Middle level of education & .0215499 & .0392851 & 0.583 \\
\hline High level of education & .0469199 & .0635826 & 0.461 \\
\hline Ends meet & $-.1963272 * * *$ & .0125439 & 0.000 \\
\hline \multicolumn{4}{|l|}{ Job characteristics } \\
\hline Permanent job & $.148134 * * *$ & .03506 & 0.000 \\
\hline Part time job & $-.1525816^{* * * *}$ & .0422626 & 0.000 \\
\hline How many hours 2 & .067964 & .0540778 & 0.209 \\
\hline How many hours 3 & -.0235485 & .0632224 & 0.710 \\
\hline How many hours 4 & .0325519 & .0837866 & 0.689 \\
\hline Health risk & $-.3272313 * * *$ & .0362259 & 0.000 \\
\hline Stress1 & $-.4357232 * * *$ & .0367746 & 0.000 \\
\hline Stress2 2 & $-.1392031^{* * *}$ & .0347872 & 0.000 \\
\hline Work affects health1 & $.1936622^{* * *}$ & .0546165 & 0.000 \\
\hline Work affects health2 & $-.379587 * * *$ & .036818 & 0.000 \\
\hline External Contacts & $.1031717 * * *$ & .0333215 & 0.002 \\
\hline Work and Family & $.2140971^{* * *}$ & .0160609 & 0.000 \\
\hline Trade Union & -.0024898 & .0302249 & 0.934 \\
\hline \multicolumn{4}{|l|}{ Relationships on the job } \\
\hline Colleagues Support1 & $-.1307048 * *$ & .0516385 & 0.011 \\
\hline Colleagues Support2 & $-.1411709 * * *$ & . .0523635 & 0.007 \\
\hline Manager Support1 & $.8107153^{* * * *}$ & .0382852 & 0.000 \\
\hline Manager Support2 & $.4218087^{* * *}$ & .0385471 & 0.000 \\
\hline Colleagues Cooperation & $-.1859295^{* * * *}$ & .0193945 & 0.000 \\
\hline Get on well Colleagues & $-.1606477 * * *$ & .0200005 & 0.000 \\
\hline \multicolumn{4}{|l|}{ Relationships outside the job } \\
\hline Volunteering & $.0905568^{* * * *}$ & .0313812 & 0.004 \\
\hline $\begin{array}{l}\text { Recreational activities } \\
\text { Job sector }\end{array}$ & $-.1065298^{* * *}$ & .0321503 & 0.001 \\
\hline Private & .0840652 & .0585129 & 0.151 \\
\hline Public & .0500317 & .0617204 & 0.418 \\
\hline \multicolumn{4}{|l|}{ Kind of occupation } \\
\hline Armed forces & .0865158 & .1898371 & 0.649 \\
\hline Managers & .1008796 & .0857548 & 0.239 \\
\hline Professionals & $.1121179^{*}$ & .0602377 & 0.063 \\
\hline Technicians & $.1023361 *$ & .0567351 & 0.071 \\
\hline Clerical & .0395089 & .0571435 & 0.489 \\
\hline Service sales & .0866457* & .0474411 & 0.068 \\
\hline Skilled agricultural forestry fish & .0827049 & .1328824 & 0.534 \\
\hline 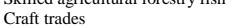 & .0375006 & .0535028 & 0.483 \\
\hline Plant machine & .0396971 & .0564284 & 0.482 \\
\hline \multicolumn{4}{|l|}{ Country } \\
\hline Austria & $.6230467 * * *$ & .1213443 & 0.000 \\
\hline Belgium & $.2376812^{* *}$ & .0921522 & 0.010 \\
\hline Bulgaria & -.1218849 & .10369 & 0.240 \\
\hline Croatia & -.0468577 & .1007336 & 0.642 \\
\hline Cyprus & -.0293453 & .1040398 & 0.778 \\
\hline Czech Republic & .1859142 & .1117324 & 0.096 \\
\hline Denmark & $-.2265344 * *$ & .1124641 & 0.044 \\
\hline Estonia & $.2567485^{* *}$ & .111347 & 0.021 \\
\hline Finland & -0897439 & .1082954 & 0.407 \\
\hline France & -.0335159 & .0975912 & 0.731 \\
\hline Germany & $.2982662 * * *$ & .0919419 & 0.001 \\
\hline Greece & .0354591 & .1091952 & 0.745 \\
\hline Hungary & .1705538 & .1183684 & 0.150 \\
\hline Ireland & .0260624 & .1107957 & 0.814 \\
\hline Italy & $.2708175^{* *}$ & .1046793 & 0.010 \\
\hline Latvia & .0029981 & .1073081 & 0.978 \\
\hline Lithuania & $-.3417761 * * *$ & .1146583 & 0.003 \\
\hline Luxemburg & -.098404 & .126064 & 0.435 \\
\hline Malta & - -1080569 & .0982393 & 0.271 \\
\hline Netherlands & .0297855 & .1282067 & 0.816 \\
\hline Poland & $.2467082^{* *}$ & .1082734 & 0.023 \\
\hline Portugal & $.2208207 *$ & .1163316 & 0.058 \\
\hline Romania & .1212194 & .1262873 & 0.337 \\
\hline Slovakia & .0363131 & .1075225 & 0.736 \\
\hline Slovenia & -.1158944 & .0934316 & 0.215 \\
\hline Spain & .0818807 & .0881794 & 0.353 \\
\hline Sweden & $-.2215406^{* * *}$ & .1031648 & 0.032 \\
\hline
\end{tabular}

$* * *$ stat. signf. at $1 \%$; ** stat. signf. at 5\%; *stat. signf. at $10 \%$. 
Table 3. Link test.

\begin{tabular}{rrrr}
\hline $\boldsymbol{S A H}$ & $\boldsymbol{C o e f f}$ & $\boldsymbol{S E}$ & $\boldsymbol{P}>|\boldsymbol{z}|$ \\
\hline hat & $1.03291 * * *$ & .0342516 & 0.000 \\
hatsq & -.0207713 & .0183674 & 0.258 \\
Number of Obs & 18616 & & \\
Pseudo R2 & 0.2651 & & \\
Prob $>\chi 2$ & 0.0000 & &
\end{tabular}

Increasing age reduces satisfaction with working conditions. There is a positive correlation between having at least a child and satisfaction with working conditions. Workers who are able to make ends meet are more satisfied with working conditions (the ability of making ends meet is expressed in a scale from 1 very easily to 6 with great difficulty). Workers with permanent job and workers with part time job are respectively more and less satisfied with working conditions. Workers who think that their health or safety is at risk because of their work, and workers who experience stress in their work (always, most of the time, sometimes) are less satisfied with working conditions than workers who do not. Workers who think that their work affects their health mainly positively and workers who think that their work affects their health mainly negatively are respectively more and less satisfied with working conditions than workers who think that their work does not affect their health. There is a positive correlation between external contacts (works that involve visiting customers, patients, clients) and satisfaction with working conditions. There is a positive correlation between the possibility of fitting working hours with family or social commitments outside work and satisfaction with working conditions. There is a negative relationship between workers' colleagues help and support (always, most of the time, sometimes) and satisfaction with working conditions. By contrast, there is a positive relationship between workers' manager help and support (always, most of the time, sometimes) and satisfaction with working conditions. Increasing good cooperation between workers and their colleagues and increasing the capacity of getting on well increase satisfaction with working conditions (both variables are expressed in a scale from 1 strongly agree to 6 strongly disagree). Volunteering and recreational activities show respectively a positive and a negative relationship with satisfaction with working conditions. Professionals, technicians and services sales workers are more satisfied with working conditions than workers employed in elementary occupations. Austria, Belgium, Estonia, Germany, Italy, Poland and Portugal are more satisfied with working conditions than the UK, while Denmark, Lithuania and Sweden are less satisfied than the UK.

Tab 4 reports the marginal effect $(d x / d y)$ of a change in regressors on the probability of being satisfied with working conditions. Marginal effects measure the expected instantaneous change in the dependent variable as a function of a change in a certain explanatory variable while keeping all other covariates constant. In a probit model, marginal effects are difficult to interpret as they are not equal to the coefficients, nor do their signs necessarily correspond to the signs of the coefficients (Long 1997). 
Table 4. Marginal effects

\begin{tabular}{|c|c|c|c|}
\hline Regressors & DX/DY & SE & $\mathbf{P}>|\mathbf{z}|$ \\
\hline \multicolumn{4}{|l|}{ Variable } \\
\hline \multicolumn{4}{|l|}{ Demographic } \\
\hline Male & .0000317 & .00503 & 0.995 \\
\hline Age 1 & $-.9882801 * * *$ & .00453 & 0.000 \\
\hline Age2 & -.8347359 *** & .03635 & 0.000 \\
\hline Age3 & $-.9865486^{* * * *}$ & .00253 & 0.000 \\
\hline Has a spouse or a partner & -.0032454 & .00517 & 0.530 \\
\hline Has a child & $.0179826 * * *$ & .00557 & 0.001 \\
\hline Middle level of education & .0035517 & .00652 & 0.586 \\
\hline High level of education & .0075084 & .00996 & 0.481 \\
\hline Ends meet & $-.0321696 * * *$ & .00392 & 0.000 \\
\hline \multicolumn{4}{|l|}{ Job characteristics } \\
\hline Permanent job & $.0258176^{* * *}$ & .00697 & 0.000 \\
\hline Part time job & $-.0266648 * * *$ & .00829 & 0.001 \\
\hline How many hours2 & .0113489 & .00928 & 0.221 \\
\hline How many hours 3 & .0039001 & .01059 & 0.713 \\
\hline How many hours 4 & .0052273 & .01319 & 0.692 \\
\hline Health risk & $-.0592197 * * *$ & .00921 & 0.000 \\
\hline Stress 1 & $-.0816117 * * *$ & .0109 & 0.000 \\
\hline Stress2 & $-.0232906^{* * * *}$ & .00639 & 0.000 \\
\hline Work affects health1 & $.0286186 * * *$ & .00786 & 0.000 \\
\hline Work affects health2 & $-.068976^{* * *}$ & .00997 & 0.000 \\
\hline External Contacts & $.0162726 * * *$ & .00535 & 0.002 \\
\hline Work and Family & $.0350813 * * *$ & .00452 & 0.000 \\
\hline Trade Union & -.000408 & .00495 & 0.934 \\
\hline \multicolumn{4}{|l|}{ Relationships on the job } \\
\hline Colleagues Support1 & $-.0204358 * *$ & .008 & 0.011 \\
\hline Colleagues Support2 & $-.0246629 * *$ & .01003 & 0.014 \\
\hline Manager Support1 & $.1557952 * * *$ & .01636 & 0.000 \\
\hline Manager Support2 & $.0585789 * * *$ & .00801 & 0.000 \\
\hline Colleagues Cooperation & $-.0304659 * * *$ & .00449 & 0.000 \\
\hline Get on well Colleagues & $-.0263233 * * *$ & .00428 & 0.000 \\
\hline \multicolumn{4}{|l|}{ Relationships outside the job } \\
\hline Volunteering & $.0144956^{* * *}$ & .00514 & 0.005 \\
\hline Recreational activities & $-.0168868 * * *$ & .00524 & 0.001 \\
\hline \multicolumn{4}{|l|}{ Job sector } \\
\hline Private & .0140635 & .0101 & 0.164 \\
\hline Public & .0080672 & .00983 & 0.412 \\
\hline \multicolumn{4}{|l|}{ Kind of occupation } \\
\hline Armed forces & .0133807 & .02768 & 0.629 \\
\hline Managers & .015528 & .01248 & 0.213 \\
\hline Professionals & $.0174092 *$ & .00904 & 0.054 \\
\hline Technicians & $.015927 *$ & .00854 & 0.062 \\
\hline Clerical & .0063425 & .00901 & 0.481 \\
\hline Service sales & $.013759 *$ & .00744 & 0.064 \\
\hline Skilled agricultural forestry fish & .0128313 & .01953 & 0.511 \\
\hline Craft trades & .006034 & .00847 & 0.476 \\
\hline Plant machine & .0063651 & .00888 & 0.473 \\
\hline \multicolumn{4}{|l|}{ Country } \\
\hline Austria & $.0679974 * * *$ & .01145 & 0.000 \\
\hline Belgium & $.0339299 * * *$ & .01192 & 0.004 \\
\hline Bulgaria & -.021505 & .01974 & 0.276 \\
\hline Croatia & 0079026 & .0175 & 0.651 \\
\hline Cyprus & -.0048958 & .01768 & 0.782 \\
\hline Czech Republic & $.0270323 *$ & .01458 & 0.064 \\
\hline Denmark & $-.042595 *$ & .02429 & 0.079 \\
\hline Estonia & $.0356808 * * *$ & .01348 & 0.008 \\
\hline Finland & -.0155342 & .01983 & 0.433 \\
\hline France & -.0056058 & .01667 & 0.737 \\
\hline Germany & $.0411148 * * *$ & .01144 & 0.000 \\
\hline Greece & .005681 & .01711 & 0.740 \\
\hline Hungary & .0250219 & .01565 & 0.110 \\
\hline Ireland & .0042012 & .01757 & 0.811 \\
\hline Italy & $.0373169 * * *$ & .0126 & 0.003 \\
\hline Latvia & .0004903 & .01752 & 0.978 \\
\hline Lithuania & $-.0689583^{* *}$ & .02833 & 0.015 \\
\hline Luxemburg & -.0171664 & .02342 & 0.464 \\
\hline Malta & -.0189011 & .01839 & 0.304 \\
\hline Netherlands & .0047878 & .02022 & 0.813 \\
\hline Poland & $.0344566^{* * *}$ & .01324 & 0.009 \\
\hline Portugal & $.0313934 * *$ & .01456 & 0.031 \\
\hline Romania & .0183664 & .01772 & 0.300 \\
\hline Slovakia & .0058143 & .01683 & 0.730 \\
\hline Slovenia & -.0203101 & .01758 & 0.248 \\
\hline Spain & .0128055 & .01321 & 0.332 \\
\hline Sweden & $-.0414643 *$ & .02215 & 0.061 \\
\hline
\end{tabular}

****stat. signf. at 1\%; ** stat. signf. at 5\%; *stat. signf. at $10 \%$. 
Workers whose age at the time of the survey interview was $15 / 34$ years; $35 / 54$ years; $55 / 74$ years have a $98.82 \%$, $83.47 \%$ and $98.65 \%$ lower probability of being satisfied with working conditions than workers whose age was $75 / 89$ years. Workers who have at least a child have an $18 \%$ higher probability of being satisfied with working conditions than workers who do not have a child. As the ability of making ends meet increases of one unit, the probability of being satisfied with working conditions increases by $3.21 \%$. Workers who have a permanent job and workers who have a part time job have respectively a $25.81 \%$ higher and a $26.66 \%$ lower probability of being satisfied with working conditions. Workers who think that their health or safety is at risk because of their work have a $6 \%$ lower probability of being satisfied with working conditions than workers who do not think that their health or safety is at risk because of their work. Workers who experience stress in their work always and most of the time and workers who experience stress sometimes have respectively an $8.16 \%$ and a $2.31 \%$ lower probability of being satisfied with working conditions than workers who do not experience stress. Workers who think that their work affects their health mainly positively and workers who think that their work affects their health mainly negatively have respectively a $2.86 \%$ higher and a $6.89 \%$ lower probability of being satisfied with working conditions than workers who do not think that their work affects their health. Workers who have external contacts (works that involve visiting customers, patients, clients) show a $1.62 \%$ higher probability of being satisfied with working conditions than workers who do not have external contacts. Who has the possibility of fitting working hours with family or social commitments outside work has a $3.50 \%$ higher probability of being satisfied with working conditions than who does not have this possibility. Workers who are helped and supported by colleagues - always and most of the time - and workers who are helped and supported sometimes have a lower probability of being satisfied with working conditions respectively of $20.43 \%$ and $24.66 \%$. While workers who are helped and supported by the manager always and most of the time and workers who are helped and supported sometimes have a higher probability of being satisfied with working conditions respectively of $15.57 \%$ and of $5.85 \%$.Increasing good cooperation between workers and their colleagues and increasing the capacity of getting on well of one unit increase satisfaction with working conditions respectively by $3 \%$ and $2.63 \%$. Workers who volunteer have a $1.44 \%$ higher probability of being satisfied with working conditions than workers who do not volunteer. Workers who practise recreational activities (sport, cultural or leisure activities) have a $1.68 \%$ lower probability of being satisfied with working conditions than workers who do not perform such activities.

Professionals $(1.74 \%)$, technicians $(1.6 \%)$ and services sales $(1.37 \%)$ have a higher probability of being satisfied with working conditions than workers employed in elementary occupations. Workers from Austria (7\%), Belgium (3.39\%), Estonia (3.56\%), Germany (4.11\%), Italy (3.73\%), Poland (3.44\%) and Portugal (3.13\%) are moresatisfied with working conditions than workers from the UK, while workers from Denmark (4.25\%), Lithuania (6.89\%) and Sweden $(4.14 \%)$ are less satisfied than workers from the UK.

\subsection{Discussion}

There are some significant correlations between demographic variables and satisfaction with working conditions.

Results do not support the U-shape relationship between job satisfaction and age (Van Praag et al., 2003; Ghinetti, 2007) for which those in the very young and old age groups are more satisfied. However, the literature is controversial with some research concluding that job satisfaction increases with age.

This is the case of our results, which could be explained considering that young workers face difficulties to access to the labour market and once they have a job not always it is a job that match with their aspirations: for this reason they are less satisfied with working conditions than older workers. Contrary to the literature (see for instance Hanson and Sloane 1992), satisfaction with working conditions is positively influenced by the presence of children. This is likely to happen according to the conventional belief that the route to happiness lies with having children: as people with children are happier, they could tend to be more satisfied in general and with working conditions as well. The ability of making ends meet, which could be considered a proxy of household income, increases satisfaction with working conditions. This result is in line with the literature (van Praag et al. 2003; Pedersen and Schmidt 2011).Labour market theory shows temporary work contracts to have a noticeable negative influence on job satisfaction, in line with the theory and with some empirical research (see for instance Wilkin 2013), workers with permanent jobs are more satisfied with working conditions. Studies that compare job satisfaction of part-time and full-time workers have shown contradictory findings: some researches indicate lower job satisfaction among part-time workers respect to full-time workers(Wotruba 1990), while some others show the contrary or no substantial difference (Miller and Tergborg 1979; Wittmer and Martin 2011). Our results show that part time workers are less satisfied with working conditions than full time workers. From a theoretical point of view, work-related stress could influence job satisfaction in two ways: 1) it could motivate workers and turn out in creativity and satisfaction, eliminating boredom; 2) it could become a negative factor associated with low job satisfaction (Halkos2010).According to the literature, results show that high levels of work stress are associated with low levels of job satisfaction. As to be expected, there is a positive association between workers' idea that their health could be undermined by their work and satisfaction with working conditions. 
In the same way, workers who think that their work affects their health mainly negatively are less satisfied with working conditions. As expected, our findings show a positive association between relationships on and outside of the job and satisfaction with working conditions. Relations count at various level for job satisfaction. People who perform jobs, which imply external contacts such as visiting customers, patients, clients, are more satisfied than people who do not have contacts outside the workplace. Therefore, interpersonal relationships, even when part of the job, seem to be not a hard component, performed by worker with effort, but show a positive correlation with satisfaction. The possibility of adjusting working hours with family or social commitments implies the opportunity of enjoying private relationships, likely for this reason, it shows a positive link with satisfaction. Indeed, some studies (Raziq and Maulabakhsha 2015)show that there are some variables, among which conflicts with family caused by job leads, which imply workers dissatisfaction.

As concerns the importance of relationships on the job for job satisfaction, results show that support by the manager has a positive association with satisfaction, while support by colleagues has a negative relationship with satisfaction. Such results are in line with Babin and Boles (1996) and it could be explained considering that support by the manager implies a kind of interpersonal relationship likely different from the one coming from support by colleagues. While the latter could be perceived as coming from an antagonist relationship within which colleagues enter into competition, perhaps to stand out with the manager, the former is perceived as a more friendly relationship within which there are no rivalries. However, good cooperation between workers and their colleagues and the capacity of getting on well show a positive relationship with satisfaction with working conditions (De Neve, Krekel, Ward 2018; Carder 2019). Good interactions on the job provide social support(Cohen and Wills 1985): making people feel accepted within the workplace; providing various kind of information and the possibility of sharing network on the job. All this produce significant advantages for workers and make them feeling better, this, in turn, could influence positively the work environment and the perception of working conditions as well.

The two measures of relationships outside of the job considered have a different association with job satisfaction with volunteering showing a positive link and recreational activities a negative one. Results suggest that, as supposed, volunteering increases satisfaction for the wage premium and career prospects, which it could imply (Fiorillo and Nappo 2014). On the other side, sporting, cultural and leisure activities do not achieve the supposed functions of ideal places where people could: find emotional and psychological support; discuss work related issues; share their work experiences. The negative link that recreational activities show with satisfaction is probably caused by internal conflicts that arise from such networks, meaning that relationships among people in those groups could become competitive instead of being supportive as expected.

\section{Conclusion}

Individuals worth relationships at any level and relationships influence individuals' lives in many ways, with consequences on health, well-being and behaviours (Durlauf2001). Interpersonal contacts on and the outside of the job may affect the perception that workers have of the working environment.

In particular, good relationships on the job can make the perception of working conditions more favourable and this, in turn, could be able to counteract less encouraging work related aspects. When workers feel satisfied with working conditions, they are likely to perform at their optimal level; by contrast, unsatisfied workers probably tent to dislike their job and, therefore, they tend to underperform.

Studying the link between interpersonal contacts on and outside of the job and satisfaction with working conditions has been the main aim of this paper. Although it was not possible to establish causality in this study (this is a limit of the paper), results show a positive association between interpersonal contacts at various level and satisfaction with working conditions meaning that relationships on and outside of the job count. Even with the above limitation, the study adds a new piece of evidence to the literature on satisfaction with working conditions. To the best of our knowledge, this is the first study, which focuses on social interactions on and outside of the job as correlates of job satisfaction in Europe. One the strengths of the paper is the sample, which includes a large set of countries: this allows providing a whole picture of the relationship between relationships on and outside of the job and satisfaction with working conditions in EU28. On the other side, the large number of countries could imply a limitation since the sample aggregates countries characterized by different work related features within working environments dissimilar among them. However, countries dummies were included in the empirical analysis and, considering the UK as reference group, in some countries (Austria, Belgium, Estonia, Germany, Italy, Poland and Portugal)workers report more satisfaction with working conditions than in others (Denmark, Lithuania and Sweden).

The paper ends with one suggestion to policymakers to support policy decisions: "firms should invest much more in employee well-being by targeting social relationships on the job..." (Global Happiness and Well-being Policy Report 2019). 
Those investments are not expensive but produce several benefits both at individual and at firm level. Good relationships on and outside of the job increase satisfaction with working conditions, which, in turn, induces workers to perform well with positive consequence on productivity and firm profitability.

\section{Bibliography}

Babin, J. B., Boles, J. S. (1996). The Effects of Perceived Co-Worker Involvement and Supervisor Support on Service Provider Role Stress, Performance and job Satisfaction. Journal of Retailing, 72(1), 57-75.

Baum, F. (1999). Social capital: Is it good for your health? Issues for a public health agenda. Journal of Epidemiology and Community Health, 53 (4), 195-196.

Becchetti, L., Pelloni, A. Rossetti, F. (2008). Relational goods, sociability, and happiness. Kyklos, 61 (3), 343-363.

Bevan, S. (2012). Good work, High performance and productivity, Paper prepared for the European HRD Forum, Lisbon, 2012, Retrieved from

http://www.theworkfoundation.com/DownloadPublication/Report/316_Good\%20Work\%20High\%20Performa nce\%20and\%20Productivity.pdf

Bruni, L. Stanca, L. (20089. Watching alone: relational goods, television and happiness. Journal of Economic Behavior\& Organization, 65 (3/4), 506-528.

Carder, B. (2019). The Happiness Effect. Quality Progress.

Chandrasekar, K. (2011). Workplace environment and its impact on organisational performance in public sector organizations. International Journal of Enterprise Computing and Business System, 1(1), 1-20.

Cohen, S., Wills, T. (1985). Stress, Social Support and the Buffering Hypothesis. Psychological Bulletin, 98, 310-357. http://dx.doi.org/10.1037/0033-2909.98.2.310

De Neve, J.E., Krekel, C. Ward, G. (2018). Work and well-being: A global perspective. In Global happiness policy report (pp. 74-128). Dubai: Global Happiness Council.

Durlauf, S. N. (2001). A framework for the study of individual behavior and social interactions. Sociological Methodology, 31, 47-87.

European Foundation for the Improvement of Living and Working Conditions, (2017), European Working Conditions Survey, 2015. [data collection]. 4th Edition. UK Data Service. SN: 8098, http://doi.org/10.5255/UKDA-SN8098-4.

European Union (2019) https://www.eurofound.europa.eu/observatories/eurwork/industrial-relations-dictionary/working-conditions

EWCS European Foundation for the Improvement of Living and Working Conditions, (2017), European Working Conditions Survey, 2015. [data collection]. 4th Edition. UK Data Service. SN: 8098, http://doi.org/10.5255/UKDA-SN-8098-4.

Fiorillo D., Nappo N., (2014). Job satisfaction in Italy: individual characteristics and social relations. International Journal of Social Economics, 41, 683-704.

Ghinetti, P. (2007). The public-private job satisfaction differential in Italy. Labour, 21 (2), 361-388.

Global Happiness and Wellbeing Policy Report (2019). Global Council for Happiness and Wellbeing. https://s3.amazonaws.com/ghwbpr-2019/UAE/GHWPR19.pdf

Halkos, G. (2010). The influence of stress and satisfaction on productivity. International Journal of Productivity and Performance Management, 59(5), 415-431.

Hanson, S. L., Sloane, D. M. (1992). Young children and job satisfaction. Journal of Marriage and the Family, 54(4), 799-811.

ILO (2016), WORKPLACE STRESS: A collective challenge.

Katzell, R. A., Thompson, D. E. (1990). An integrative model of work attitudes, motivation, and performance. Human Performance, 3, 63-85.

Maslow, A. H. (1954). Motivation and personality. New York, NY: Harper and Row.

McKenzie, K., Whitley, R., Weich, S. (2002). Social capital and mental health. British Journal of Psychiatry, 181 (4), 280-283.

Miller, H.E. Terborg, J.R. (1979). Job attitudes of part-time and full-time employees. Journal of Applied Psychology, 64 (4), 380-386.

Morrison, R. (2004). Informal relationships in the workplace: Associations with job satisfaction. New Zeland Journal of Psychology, 33, 114-128.

Naharuddin, N. M., Sadegi, M. (2013). Factors of Workplace Environment that Affect Employees Performance: A Case Study of Miyazu Malaysia. International Journal of Independent Research and Studies, 2(2), 66-78. 
Nappo, N. and Verde, M. (2010). Volontariato, Beni Relazionali e BenessereSoggettivo. Rivista di PoliticaEconomica, $100(2), 363-392$.

Pedersen, P.J. and Schmidt, T.D. (2011). Happiness in Europe. Cross-country differences in the determinants of satisfaction with main activity. Journal of Socio-Economics, 40 (5), 480-489.

Pires, M.L. (2018). Working conditions and organizational support influence on satisfaction and performance. European Journal of Applied Business Management,Special Issue of ICABM2018, 162-186.

Ponzo, M. and Scoppa, V. (2010). The use of informal networks in Italy: efficiency or favoritism?.Journal of SocioEconomics, 39 (1), 89-99.

Raziq, A., Maulabakhsh, R. (2015). Impact of Working Environment on Job Satisfaction. Procedia Economics and Finance, 23, 717-725.

Robbins, S.P., Judge, T.A. (2013). Organizational behaviour fifteenth edition. New York: Pearson Prentice Hall. EBook.

Van Praag, B.M.S., Frijters, P., Ferrer-i-Carbonell, A. (2003). The anatomy of subjectivewell-being. Journal of Economic Behavior\& Organization, 51 (1), 29-49.

Wilkin, C. L. (2013). I can't get no job satisfaction: Meta-analysis comparing permanent and contingent workers. Journal of Organizational Behavior, 34(1), 47-64.

Wilson, J. (2000). Volunteering. American Sociological Review, 26 (1), 215-240.

Wittmer, J.L.S. and Martin, J.E. (2011). Work and personal role involvement of part-time employees: implications for attitudes and turnover intentions. Journal of Organizational Behavior, 32 (5), 767-87.

Wotruba, T.R. (1990). Full-time versus part-time salespeople: a comparison on job satisfaction, performance, and turnover in direct selling. International Journal of Research in Marketing, 7(2-39), 97-108. 